\title{
Bokrecension: Why Students Resist Learning. A Practical Model for Understanding and Helping Students
}

\author{
Jenny Katarina Eklöf \\ Universitetslektor, Umeå universitet
}

Why Students Resist Learning: A Practical Model for Understanding and Helping Students. Redigerad av Anton O. Tolman och Janine Kremling. Stylus Publishing, Llc., 20I7

I boken Why Students Resist Learning. A Practical Model for Understanding and Helping Students gör redaktörerna Anton O. Tolman, professor i psykologi vid Utah Valley University, och Janine Kremling, docent i straffrätt vid California State University, San Bernardino, ett allvarligt försök att förstå vad som händer när studenter motsätter sig undervisning eller ger upp försöken att lära sig. Bokens huvudfråga handlar om att öka förståelsen för hur motstånd uppträder och kommer till uttryck, men också att gå till botten med motståndets orsaker, att skapa förstålse för de många olika faktorer som lägger hinder i vägen för ett aktivt och engagerat lärande. Boken utgår från en amerikansk högskolekontext där vissa historiska, ekonomiska och politiska aspekter inverkar på studenters motstånd på ett sätt som inte har exakta motsvarigheter i Sverige. Däremot är bokens insikter om motståndets orsaker och mekanismer överförbara till en svensk eller europeisk kontext överlag.

Huvudpoängen i boken är att studenters uppvisade motstånd mot lärande inte beror på egenskaper som studenten bär med sig in i undervisningen och som vi enkelt kan avfärda med att studenten inte hade rätt förutsättningar till att börja med. Istället kan motståndet ses som en konsekvens av studenternas tidigare erfarenheter; upplevelser i klassrummen, förväntningar hemifrån och från vänner, intryck från hela den institutionella kultur inom vilken utbildningen befinner sig och så vidare. Författarna presenterar en analytisk ram som integrerar alla dessa olika faktorer genom en modell, IMSR (Integrated Model of Student Resistance), som också är tänkt att vara till praktisk hjälp för universitetslärare när de möter studentmotstånd i sin egen undervisning. För den som inte i huvudsak är intresserad av dessa frågor för sin egen forskning är själva modellen mindre intressant, men däremot har läsaren stor behållning av att boken väver samman resultat och resonemang från många för ämnet relevanta forskningsområden. En av de starkaste sidorna med boken är också att studenternas röster kommer med på ett sätt som verkligen bidrar med substans och djup. Överhuvudtaget är det inte vanligt att böcker om högskolepedagogik inkluderar avsnitt författade av studenter. Istället reduceras ofta studentperspektivet till kortfattade fall eller exempel, gärna inklämda i en liten ruta någonstans. Här kommer istället studenterna till tals och står som medförfattare till flera av bokens ingående kapitel.

Huvudförfattarna har det studerandeaktiva lärandet i fokus för många av sina resonemang, och utgår från det välkända problemet att inte alla studenter uppskattar eller förstår studerandeaktiva

*Författarkontakt: jenny.eklof@umu.se

Artiklar och reflektioner är kollegialt granskade. Övriga bidragstyper granskas av redaktionen. Se www.hogreutbildning.se ISSN 2000-7558

(C)2018 Jenny Katarina Eklöf. This is an Open Access article distributed under the terms of the Creative Commons Attribution-NonCommercial 4.0 International License (https://creativecommons.org/licenses/by-nc/4.0/), allowing third parties to share their work (copy, distribute, transmit) and to adapt it, under the condition that the authors are given credit, that the work is not used for commercial purposes, and that in the event of reuse or distribution, the terms of this license are made clear.

Citation: Jenny Katarina Eklöf (2018) «Bokrecension: Why Students Resist Learning. A Practical Model for Understanding and Helping Students», Högre utbildning 8(2), 69-71. http://dx.doi.org/10.23865/hu.v8.1408 
upplägg. Vanliga problem kan vara att studenterna känner sig snuvade på "riktig undervisning" (läs föreläsningar), att de bär med sig dåliga erfarenheter av grupparbeten från tidigare kurser eller att de helt enkelt inte känner sig förberedda på att axla det ansvar det innebär att vara medskapare av kursen. Detta i sin tur kan manifesteras genom olika former av aktivt eller passivt motstånd. Det passiva motståndet visar sig till exempel genom att studenter inte kommer till lektioner, att de drar sig tillbaka i klassrumsdiskussioner, att de försöker göra så lite som möjligt utan att bli underkända, att de klagar på läraren inför sina studiekamrater eller att de lämnar in uppgifter för sent. Det aktiva motståndet kan ta sig uttryck i att studenter högljutt opponerar sig i klassrummet och saboterar undervisningen, att studenter i samlad grupp går "högre upp" till studierektor eller prefekt för att klaga, att de vägrar delta i olika aktiviteter eller uppgifter eller att de hoppar av kursen eller programmet. Ambitionen med boken är att möjliggöra för lärare (och studenter) att på ett tidigt stadium kunna identifiera motstånd när det uppträder, och detta är enligt författarna bara möjligt om man först förstår dess orsaker. Finns denna förståelse går det bättre att hitta lämpliga och effektiva strategier för att bemöta och reducera motståndet.

Bokens viktigaste bidrag avseende dess praktiska användning ligger i hur den uppmuntrar till reflektion och självrannsakan hos både studenter, lärare och pedagogiska ledare och utvecklare. Boken handlar intressant nog inte bara om studenters motstånd, utan också om vikten av att lärare vänder spegeln mot sig själva och reflekterar över sitt eget medansvar till att studenter uppvisar passivt eller aktivt motstånd, men också över sitt eget eventuella motstånd till förändring och utveckling.

Boken lyfter fram exempel på situationer där lärare faktiskt själva är medansvariga till studenters bristande motivation, engagemang eller direkta motstånd. Det kan handla om lärare som inte förbereder studenter tillräckligt väl inför olika uppgifter, vilket skapar osäkerhet och otrygghet. Det kan handla om lärare som gör sig okontaktbara och inte vill svara på frågor och som ser frågorna som ett tecken på studenternas omognad och osjälvständighet. Det kan handla om lärare som inte ingriper när studentgrupper inte fungerar, eller som inte ser eller förstår de sociala dimensionerna av lärandet. Det kan handla om lärare som tydligt visar att de bär på uppfattningen att bara vissa studenter är lämpade för högre studier, och att övriga inte hör hemma på universitetet (fel intelligens, fel kön, fel bakgrund).

Men motstånd kan också vara en respons på faktorer som ligger på en annan nivå, i organisationen eller i kulturen. Exempelvis kan en högskolepolitik och ett meriteringssystem som sätter forskningsmeriter i första rummet, och pedagogisk kompetens i det andra, signalera till studenter att de egentligen inte är riktigt viktiga. När möjligheter för lärare att göra karriär kräver att de erhåller forskningsmedel och helst ska kunna "köpa sig fria" från undervisning, underminerar det lärares långsiktiga engagemang för undervisning, vilket indirekt påverkar studenters motivation och motstånd. När seglivade könsstrukturer leder till en mycket ojämn könsfördelning bland professorer, talar naturligtvis detta förhållande sitt tydliga språk. För studenter som aspirerar på att göra akademisk karriär ser förutsättningarna för lärandet olika ut beroende på vilket kön du tillhör. Det kan också handla om sådant som att universitet och högskolor idag har trycket på sig att konkurrera på en global kunskapsmarknad, och därför lanserar sina nya utbildningsprogram med hjälp av påkostad marknadsföring i vilken studenter inte sällan jämställs med kunder. Påståenden i marknadsföringen om universitetet och dess pedagogiska excellens, kompetens och kvalitet kan - om de visar sig inte stämma överens med verkligheten - generera besvikelse och motstånd när studenterna väl påbörjar sin utbildning.

Författarna till boken vänder också på perspektivet och diskuterar även hur lärare aktivt eller passivt kan motverka lärande och utveckling. Ett sådant exempel kan vara när lärare väljer 
att göra kosmetiska istället för genomgripande förändringar av en utbildning som fått kritik. Det senare alternativet kräver förmåga till omprövning och självgranskning, något som utgör ett större hot mot lärares självbild, men samtidigt bidrar med mer djuplodande kvalitetsutveckling. Ett annat exempel kan vara när lärare motsätter sig extern granskning därför att de uppfattar att granskningen inte tar hänsyn till ämnens särart, att det enda som värderas är det i siffror omvandlingsbara, och att deltagandet $i$ granskningen är påtvingat och drivet av en rädsla för svaga granskningsresultat och hotet om indragen examensrätt. Vid sådana tillfällen muttrar lärare i korridorerna och visar sitt passiva motstånd på ungefär samma sätt som studenter gör när de inte förstår meningen med en examination, anser att bedömningskriterierna är orättvisa, samtidigt som de är medvetna om att svaga resultat kan leda till dåliga betyg, uteblivna poäng och indragna studiemedel.

Författarnas växling mellan studentperspektivet och lärarperspektivet gör att det går lättare att få förståelse för och känna empati med både kämpande studenter och lärare. Det boken ger är en struktur åt tanken, berättelser att leva sig in i och många mer eller mindre vetenskapligt förankrade tips som går att reflexivt applicera på den egna undervisningspraktiken. Förståelsen för hur politiska, ekonomiska och kuturella faktorer inverkar på den lärsituation som både studenter och lärare är inbegripna i, samt medskapare till, är den här bokens största behållning. 